\title{
Voicethread: A Technology Tool Worth Your Time
}

\author{
Dawn Haverkate-Ens
}

\section{Introduction}

I have worked at the Applied English Center since 1991 and over that time the kinds of technology I have had access to have changed dramatically. The technology we now have access to makes teaching spoken English much easier. In the following article, I address three key questions about Voicethread and why I think it is worth learning about and using with your students. Caveats are also discussed but the drawbacks do not outweigh the benefits. In the following discussion Voicethread with a capital V refers to the program and voicethread with a small $\mathrm{v}$ refers to an individual voicethread that the user has created.

\section{What is Voicethread?}

Voicethread is an online sharing tool that enables users to add images, documents, and videos, and to which other users can add voice, text, audio or video comments. It is asynchronous-meaning users can access it at different times and each time they do their additions will be saved.

A voicethread can also be set up as a presentation which does not allow comments. You can post a link to the voicethread's webpage address on your Blackboard website or send an invitation to a voicethread by sending the web address via e-mail. Visually it looks like a collection of slides with images at the center of each slide. When people comment, a small icon at the edge of the slide indicates that someone has commented.

Figure 1. Screenshot of sample voicethread

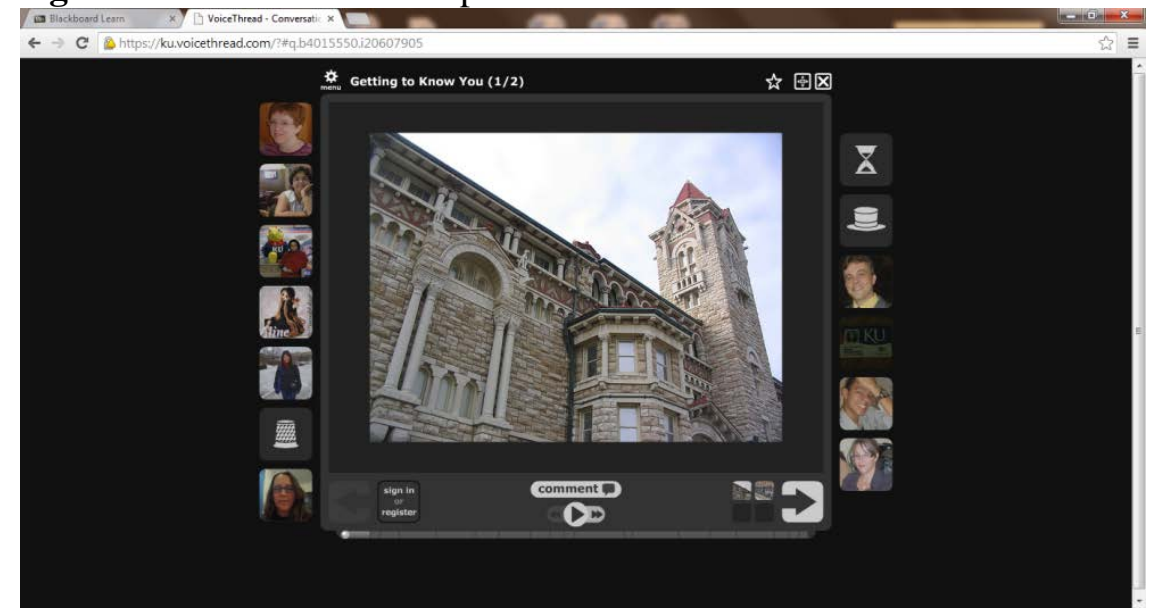

Figure 1. A screenshot view of a voicethread, which indicates slide views as well as icons of people who are able to comment on the voicethread.

A voicethread is fairly easy to create. So easy that it is possible to quickly teach students to create their own and share their creation with their teacher, their fellow students, or both and easily get written and audio feedback on what they have created. The fact that students can so easily communicate with each other in an environment that incorporates graphics means there are many potential ways Voicethread can enrich the learning experience.

\section{Why Voicethread Is an Exciting Educational Tool}

When I first understood what Voicethread could do, I was impressed. Rarely do I come across a technology tool that has such a user-friendly interface and such potential for the classroom and learning outside the classroom. When I assess any tool I want to know how much time it will take to learn to use, how accessible it will be and if my time invested in it will likely pay off. I find that Voicethread is quickly learned, highly accessible, and is well worth the time it takes to learn it.

Voicethread is cloud-based, so it is available anywhere. KU has bought licenses for all faculty and students, so it is available to everyone, and it is a tool that is being used by many universities. I believe it will have some staying power. 
A voicethread has the potential of creating an online environment where real communication can take place and where the audience is anyone who visits the voicethread. If a voicethread is set up well, it can motivate participants to record thoughtful responses and craft their spoken language for a specific purpose, and since they know others (and not only their teacher) will hear them, they will be motivated to speak well.

Finally, it is fun. There is something about combining visuals and voice in this format that is inherently motivating. The way a voicethread can combine images and voices can result in a fascinating kind of virtual space that can motivate all of us to communicate. And because of its flexible format, it can be used for a variety of purposes: from formal presentations or explanations where you do not want people to comment, to spaces where the purpose is to hear everyone's reactions, such as discussions of or reactions to a topic.

There is an extensive amount of documentation on how to use Voicethread, including instructional videos and written documentation. A good place to start is the instructional voicethreads you have access to once you login to your account. KU faculty can start by logging in at http://technology.ku.edu/voicethread. At the end of this article you will find additional links you may find helpful.

\section{How I Have Used Voicethread}

\section{Class Bonding}

My first attempt to use Voicethread with a class was very informal. I had a very small class that bonded very well over the semester. At the end of the semester we had a dinner party at my house and I took several pictures. I made a voicethread and uploaded those pictures and some of my comments, inviting the students to add their own. It was a great way to share the pictures. Only a few people commented, but we had not used this tool during the semester so it was a bit unfamiliar to them.

\section{Teaching Outside of Class}

For my Level 3 Listening/Speaking class I created a voicethread with an explanation of the stress/intonation of compound nouns and adjective + noun combinations in English which included a final section asking the students to pronounce a list of these structures. I posted the voicethread in Blackboard so that students outside of class could review the explanation I had given in class outside of class and show me they understood by doing a recording task.

\section{Class Bonding/Recorded Presentation}

In spring 2013, I worked with a group of very experienced Brazilian English teachers and used a voicethread at the beginning of the class as a way for the teachers to introduce themselves, where they were from and their teaching situations in Brazil. I loved how after they had made these recordings, they could access the voicethread at any time to listen to their colleagues and that some of the teachers of other sections were able to listen to their recordings as well (with their permission). I also assessed some of their spoken English by creating tasks they had to complete in a voicethread. In addition, as part of their digital portfolios for the program, the teachers created a voicethread in which they answered a few questions about their lesson plans.

\section{Facilitating Meetings}

I also believe that Voicethread, used well, could facilitate interaction between teachers, making meetings more productive and making meetings possible even when it is not possible to get everyone in the same room. At the end of one semester I used Voicethread as a virtual meeting space. I first covered information everyone needed to be aware of and then asked the teachers for thoughtful feedback on a few questions related to how certain aspects of their classes went. If done well, I believe that this can result in thoughtful input for the group and more efficient use of time.

\section{How I Hope to Use Voicethread in the Future}

\section{Fostering Discussion Skills}

I would like to incorporate more Voicethread projects into my class, creating contexts in which they can contribute to meaningful discussions. The ease with which people can hear themselves and then edit their recordings makes this a powerful tool for improving their skills in this area. 
Recorded Lessons/Explanations (a.k.a. Flipping the Classroom)

I would like to invest time in creating teaching presentations which I can assign students to watch outside of class. Having a bank of these kinds of lessons would make it easy to customize curriculum to meet students' needs. This would be especially useful for teaching certain aspects of pronunciation, for example, and you could ask students to record something to show they understand a concept by their production of the correct sound/intonation. Making explanation videos about presentation assignments is another possibility. I could assign the presentation and then encourage students to listen again outside of class if they need more clarification.

\section{Student-created Presentations}

I would also like to have students create a presentation in Voicethread, following my guidelines. They would then be asked to view their own and other students' presentations and ask questions/give feedback. After they had created it, they could easily share the voicethread with their parents or others via the url link.

\section{Caveats}

Voicethread can be used in so many different ways that I would guess many teachers could find ways of using it to accomplish their objectives. Like all technology, however, there is a learning curve and it takes some time to learn the program. You also need to take time to wrap your head around what it can do and think about how best to use it.

Comparing what Voicethread does with other tools we already have access to (e.g. WIMBA voiceboards in Blackboard) is a worthwhile task. If you really just want students to do simple recording at home, however, something like Voiceboards (WIMBA) may be a preferable tool.

Furthermore, creating a quality presentation in Voicethread takes some time. If you do, though, choose to invest that time in creating an instructional video presentation for your students, that presentation can be used again and again within your Blackboard course. If you think ahead, you can have your students react to the same voicethread each semester by creating a master "clean" Voicethread which you copy for use each semester.

Finally, if you choose to have your students create Voicethreads, you must really think about how much training and setup will be necessary so that all parties will be happy with the results. Even though the interface is user-friendly, students need to be trained to use it and practice using it before they are expected to create their own.

\section{Helpful Links}

Sample Voicethreads that have been used at the university level: http://voicethread4education.wikispaces.com/College

Dawn's voicethread about stress in compound nouns: https://ku.voicethread.com/?\#u2762029.b4447753.i22647320

Good starting point for AEC faculty:

Blackboard $>>$ AEC Teacher Technology Resources>>Voicethread

Webinar about how ESL teachers are using Voicethread including Spanish verb tense exercises and virtual writing conferences with beginning ESL writers:

Pacansky-Brock, M. (2012, 04 26). Reinventing Language Learning with Voicethread. [Webinar]. Retrieved from http://blog.voicethread.com/webinars/reinventing-language-learning-with-voicethread/ 